\title{
ARVOSTELUJA
}

\section{Yhdyssanojen rajankäyntiä Agricolan sanastossa}

TANJA ToRopainen: Yhdyssanat ja yhdyssanamaiset rakenteet Mikael Agricolan teoksissa. Turun yliopiston julkaisuja, sarja C, osa 439. Scripta Lingua Fennica Edita. Turku 2017. http://urn.fi/ URN:ISBN:978-951-29-6875-6. $122+121$ sivua.

Vanhaa kirjasuomea koskevassa tutkimuskirjallisuudessa toistetaan usein, että sanojen yhteen ja erilleen kirjoittaminen on Ruotsin vallan aikana ollut vaihtelevaa, mutta havainnon tueksi ei ole ollut juurikaan näyttöä tähän variaatioon vaikuttavista tekijöistä tai kirjoittajakohtaista vertailua. Erillistutkimuksia vanhan kirjasuomen yhdyssanarakenteista on julkaistu varsin vähän, nekin enimmäkseen suppeita artikkeleita.

Tanja Toropaisen artikkeliväitöskirja Mikael Agricolan teoksissa esiintyvistä yhdyssanoista ja yhdyssanamaisista rakenteista on tervetullut lisä tähän tutkimukseen. Tässä arviossa tarkastelen pääosin väitöskirjan yhteenveto-osaa.

Väitöskirjan taustalla on Turun yliopiston hanke, jossa on tuotettu Mikael Agricolan teoksista morfosyntaktinen tietokanta (hankkeesta tarkemmin esim. Inaba 2007). Toropainen on ollut hankkeessa mukana hakusanoittamassa Agricolan teoksissa esiintyviä sanoja, ja tätä kokemusta tutkija on päässyt hyödyntämään käsillä olevassa väitöstutkimuksessa.

\section{Tutkimuksen tavoitteet ja näkökulmia yhdyssanoihin}

Yhdyssanoja voi lähestyä sekä sananmuodostuksen että ortografian näkökulmasta. Tanja Toropaisen tutkimuksessa näkökulmat yhdistyvät. Sanastoa ja sananmuodostusta käsittelevässä kirjallisuudessa yhdyssanat tuppaavat herkästi jäämään johtamisen varjoon. Toropainen osoittaa, että myös sanojen yhdistämisen mekanismeissa riittää selvitettävää. Yhdyssanojen synnyn selvittelyssä on toki otettava huomioon, että yhdyssana voi syntyä myös johtamalla (ylenpalttinen $>$ ylenpalttisuus) ja että yhdyssanoja voi rekursiivisesti yhdistää jälleen uusiksi yhdyssanoiksi (naaras + jalopeura $>$ naarasjalopeura).

Mikael Agricolan ortografiaa on tutkittu paljonkin, mutta menneinä vuosikymmeninä tutkijoiden kiinnostus on keskittynyt lähinnä äänteiden ja kirjainten vastaavuuden selvittelyyn (esim. Rapola 1933). Toropaisen väitöskirja on ensimmäinen erillistutkimus yhdyssanojen yhteen ja erilleen kirjoittamisesta Agricolan teoksissa. Aikasuhteiltaan tutkimus on pääosin synkroninen: tutkimuksessa pitäydytään 1500-luvulla, paitsi ensimmäisessä osa-artikkelissa, jossa tarkastelujaksona on koko vanhan kirjasuomen kausi.

Toropainen määrittelee tavoitteikseen kuvata morfologisesti Agricolan teosten yhdyssanarakenteita, selvittää joidenkin yhdyssanarakenteiden alkuperää, tarkastella joidenkin yhdyssanarakenteiden vakiintumista sekä arvioida yhdyssanan käsitettä vanhan kirjakielen aineiston perusteella. Ortografia ei suoraan näy näissä tavoitteissa, mutta se on ollut läsnä paitsi 
osa-aineistojen rajausperusteena myös kautta koko prosessin tutkimuksen lähtökohtien hahmottelusta aina tutkimustulosten raportointiin asti. Kun tutkimuskohteena ovat vanhan kirjasuomen yhdyssanat, sanayhtymien yhteen ja erilleen kirjoittamisen vaihtelu on otettava huomioon joka vaiheessa.

Yhdyssanoja on kieliopeissa tarkasteltu sekä deskriptiivisesti että normatiivisesti, mutta tutkimuskohteenakin yhdyssanat tuntuvat suorastaan kutsuvan esiin (kirjoitetun) kielen normittamisen ja joko-tai-ajattelun: Kumpi on oikein, nominatiivi- vai genetiivialku? Pitääkö sanayhtymä kirjoittaa yhteen vai erilleen?

Tutkimuksessaan Toropainen on tietoisesti pyrkinyt irtautumaan nykykielen normatiivissävytteisestä yhdyssanakäsityksestä; niinpä esimerkiksi savinenastia on tulkittu aidoksi yhdyssanaksi, ei vahingossa yhteen kirjoitetuksi sanaliitoksi eikä ladontavirheeksi. Deskription ja normittamisen ristiveto näkyy myös Toropaisen lähdeluettelosta, jossa on deskriptiivisten kielioppien rinnalla myös jokunen normatiivinen kielenkäytön opas.

Nykykielen yhdyssanakäsityksestä irrottautuminen on Toropaiselta keskeinen teoreettinen kannanotto. Siksi aiheen käsittely olisi mielestäni kuulunut pikemminkin Teoreettinen viitekehys- kuin Aineistot ja menetelmät -lukuun.

\section{Tutkimusprosessi näkyvillä myös lopputuotteessa}

Tanja Toropaisen väitöskirja koostuu viidestä aiemmin julkaistusta artikkelista ja yhteenvetoluvusta. Artikkelit muodostavat monipuolisen kokonaisuuden, jonka tekijä onnistuu yhteenvedossa kehystämään ilman toisteisuuden vaikutelmaa. Yhteenvedosta lukija saa myös lisävalaistusta joillekin ratkaisuille, jotka itse artikkeleissa ovat jääneet turhan niukasti dokumentoiduiksi. Mukana on kolme laajaa liitettä: luettelot Agricolan teosten yhteen kirjoitetuista yhdyssanoiksi tulkituista rakenteista (paitsi numeraaleista) esiintymämäärineen, erilleen kirjoitetuista luontaisista yhdyssanoista sekä yhteen kirjoitetuista sanajonoista, joita tutkimuksessa ei ole tulkittu yhdyssanoiksi (esim. nouseyles).

Artikkeliväitöskirjassa tutkijan kulkema matka näkyy selvemmin kuin monografiassa, jossa kaikkea tekstiä voi muuttaa vielä esitarkastuksen jälkeen ja työprosessi jää piiloon. Artikkeliväitöskirjaan artikkelit tulevat siinä muodossa kuin ne on aikoinaan julkaistu. Varhaisin Toropaisen väitöskirjaan sisältyvistä artikkeleista on ajalta 14 vuotta ennen väitöstä ja poikkeaa aineiston aikarajauksen puolesta muista, koska ajatus nimenomaan Agricolan yhdyssanoja koskevasta väitöstutkimuksesta heräsi vasta myöhemmin. Yhteenveto-osassa tutkija pääsee kommentoimaan ja täydentämään artikkeleitaan. Toropainen muun muassa suhteuttaa toisiinsa eri artikkeleissa käyttämiään termejä ja esittelee hyödyntämiään vertailuaineistoja.

Toropainen on pyrkinyt laatimaan Agricolan sanastosta kuvauksen, jossa yhdyssanarakenteet tulevat kuvatuksi sanaluokittain. Tässä väitöskirjagenren sallima laajuus - ja varmaan aikakin - on asettanut omat rajansa, ja osatutkimuksissa tulevat käsitellyksi vasta yhdysverbit ja -adjektiivit sekä osa yhdyssubstantiivien rakennetyypeistä. Niinpä tekijä on päätynyt artikkeliväitöskirjalle poikkeukselliseen ratkaisuun: yhteenveto sisältää (luvun 5 alaluvuissa) myös uutta, artikkelien jälkeistä tutkimusta Agricolan yhdyssanojen sanaluokittaisista yleisyyssuhteista sekä yhdyspronominien, -numeraalien, -adverbien ja -interjektioiden rakennetyypeistä. Yhteenveto siis sisältää tavanomaiseen artikkeliväitöskirjaan verrattuna ylimääräistä, mutta ei tiedekunnan ohjeissa suoranaisesti kiellettyä ainesta (Ohje Artikkeliväitöskirja humanistisessa tiedekunnassa 2017-2018). 
Vaikka ratkaisu onkin epäsovinnainen, mielestäni siitä ei ole koitunut kokonaisuudelle mitään haittaa, saahan lukija lisäanalyyseista kehykset - vaikka osin vasta alustavat - artikkeleissa esitetyille tutkimustuloksille. Yhteenveto myös antaa tavanomaista jatkotutkimusaiheiden listaamista vahvempia viitteitä siitä, että tutkimustyö jatkuu väitöskirjan valmistuttuakin.

\section{Onko yhdys sana yhdyssana?}

Tanja Toropaisen tutkimuksessa keskeinen kysymys kuuluu, mikä on yhdyssana ja mikä ei. Yhdyssanan käsitettä koskevassa alaluvussa Toropainen esittelee muun muassa yhdyssanan prototyypin, jonka Laura Tyysteri $(2015,26)$ on hahmotellut nykysuomen yhdyssanatyyppien produktiivisuutta käsittelevässä tutkimuksessaan. Prototyyppinen yhdyssana koostuu itsenäisistä lekseemeistä, sen osien välinen raja vastaa syntaktista rajaa, eikä sitä vastaava sanaliitto ole mahdollinen syntaktinen rakenne. Semanttisesti yhdyssanan prototyyppi on eriytynyt osistaan ja kiteytynyt yksittäisen käsitteen nimitykseksi, ja morfologisesti se on eheä ja koskematon kokonaisuus. Puheessa sillä on yksi pääpaino. Palataan myöhemmin siihen, missä määrin Agricolan yhdyssanat noudattavat tätä prototyyppiä.

Yhdyssanaa siis sitovat yhteen monet muutkin piirteet kuin se, että se (kielikohtaisesti) kirjoitetaan yhdeksi kokonaisuudeksi. Nykysuomen sanayhtymien yhteen ja erilleen kirjoittaminen on varsin pitkälle normitettua, mutta emme voi luottaa siihen, että Agricola olisi kirjoittanut kaikki yhteen kuuluviksi mieltämänsä merkityskokonaisuudet yhteen.

Väitöskirjan nimessä puhutaan yhdyssanoista ja yhdyssanamaisista rakenteista, siis rakenteista, jotka "muistuttavat esimerkiksi muotonsa, osiensa, muodostustapansa tai merkityksensä puolesta yhdyssanoja, mutta ovat kuitenkin jotain muuta". Sanaliittojako? Kielenhuollon piirissä yhdyssanan vastaparina esiintyy usein sanaliitto, joka terminä kuitenkin korostaa sanojen erillisyyttä: yhdyssana on yksi sana, sanaliitto kaksi sanaa (joskus useampiakin).

Kun sanaliitto-termin edus- ja määriteosat vaihdetaan keskenään, saadaan tulokseksi liittosana, kätevä nimitys lekseemeille, jotka muodostuvat kahdesta erilleen kirjoitetusta osasta. Mutta Toropainen mahduttaa yhdyssanamaisiin rakenteisiin myös ne (erheellisesti) yhteen kirjoitetut tapaukset, jotka eivät kuitenkaan aidosti ole yhdyssanoja eivätkä edes liittosanoja.

Koska Toropainen käy tutkimuksessaan yhdyssanojen ja sanaliittojen/liittosanojen rajaa, tarvitaan kattotermiä, jonka alle mahtuvat molemmat ryhmät. Tällaisena kattoterminä Toropaisella on sanayhtymä. Sanayhtymä voi olla yhtä lailla yhdyssana kuin samoista osasanoista muodostunut lauseke; termin käyttöön ei sisälly kannanottoa siihen, edustaako yhtymä lekseemiä (Koivisto 2013, 328).

Monet suomen kielen yhdyssanarakenteet ovat sellaisia, että kielessä on myös vastaava kaksisanainen syntaktinen rakenne. Tällöin etenkin erilleen kirjoitetuista esiintymistä voi olla vaikea tulkita, onko rakenne yhdyssana vai sanaliitto. Yhdyssanarakenteesta ei kuitenkaan esiinny vastaavaa kaksisanaista lauseketta, kun yhdyssanan määriteosana on nominatiivimuoto (alkupuhe), yhdysosamuoto (syömähammas) tai lekseeminä esiintymätön nominivartalo (esipuhe). Tällaisille yhdyssanoille Toropainen on muodostanut hyvin käyttökelpoiselta tuntuvan nimityksen: hän kutsuu niitä luontaisiksi yhdyssanoiksi. Veikkaanpa, että termi leviää laajempaankin käyttöön. Ja kyllä, yhdys sana on siis katkonaisesta kirjoitusasustaan huolimatta luontainen yhdyssana. 


\section{Keskiössä aineisto}

Väitöskirjansa aineistona Tanja Toropaisella on - ainakin periaatteessa - Mikael Agricolan teosten yhdyssanat; osatutkimuksissa hän tarkastelee eri tavoin rajattuja osa-aineistoja, ja niiden kohdalla voi tosiaankin puhua "täydellisistä aineistoista", jotka sisältävät kaikki tutkittavan rakennetyypin esiintymät Agricolan teoksissa. Tutkimus on kautta linjan vahvasti aineistopohjaista, ja tulevien kielentutkijoiden kannattaakin lukea tarkoin Toropaisen pohdinnat eri tavoin koostettujen aineistojen ääressä.

Osatutkimuksissaan Tanja Toropainen on käyttänyt aineistona sanakirjan toimittamista varten tehtyjä sanalippuja, Agricolan morfosyntaktisen tietokannan koodattua sanalistaa, Kotimaisten kielten keskuksen Vanhan kirjasuomen korpusta, Index Agricolaensis -saneluetteloa (IA) ja Mikael Agricolan teosten näköispainosta (MAT). Näistä hän on koostanut kutakin osatutkimusta varten erillisen Access-tietokannan, josta pääsee kätevästi tekemään hakuja ja jossa laskutoimitukset sujuvat sukkelasti. Hyvästi ruutuvihko ja tukkimiehen kirjanpito!

Toropainen erittelee käytännönläheisellä otteella erilaisten aineistotyyppien tarjoamia mahdollisuuksia ja sudenkuoppia. Mielestäni käsillä olevan tutkimuksen keskeisimpiin anteihin kuuluukin juuri se havainto, miten kiinteä yhteys aineiston laadulla ja rajausperusteilla on niin tutkijan työprosessiin kuin tutkimustuloksiinkin. Toropaisen työ herättää lukijan pohtimaan laajemminkin, mihin ja miten sähköisiä aineistoja voi hyödyntää, kuinka luotettavia ne ovat ja miten niiden muutoksenhallinnasta on huolehdittu.

Vanhan kirjasuomen sanankirjan (VKS) toimittamista varten laadittujen sanalippujen äärellä Toropainen ihmetteli, kuinka yhdysverbilipuissa on saatettu merkitä hakusanan määriteosa sulkeisiin tai siirtää se edusosan jälkeen, vaikka se lippuun poimitussa esiintymässä on kiistatta verbin edellä. Jotkin yhdysverbiliput on myös aakkostettu edusosan mukaan. Tutkijalle syntyi "vaikutelma, että prefiksialkuisuus on yritetty suorastaan häivyttää lekseemeistä", ja hän joutui käymään sanaliput uudelleen läpi, kun oli ensimmäisellä kierroksella poiminut aineistoonsa vain ne verbit, jotka sanastajatkin olivat hakusanoittaneet yhdysverbeiksi. Uusintakierroksella Toropainen perehtyi tarkemmin sanalipuissa oleviin esimerkkilauseisiin, joista verbien käyttöyhteys ja merkitys hahmottuvat paremmin.

Digitoitujen tekstiaineistojen yhtä lailla kuin sanalippujenkin ääressä on syytä muistaa, että ne ovat ihmisten tekemiä ja että aineiston ilmiasu perustuu tehtyihin valintoihin. Kun tutkimuskohteena ovat yhdyssanat, myös sillä on merkitystä, mitä tapahtuu rivin vaihtuessa. Agricolan teoksissa riviltä toiselle jatkuvaan yhdyssanaan on usein merkitty yhdysmerkki, mutta se on voitu jättää poiskin tilan puutteessa tai visuaalisesti harmonisen sivukokonaisuuden luomiseksi. Jos rivin lopussa on yhdysmerkki, onko se vain rivinvaihdosta johtuva ratkaisu vai onko yhdysmerkkiä käytetty saman sanan yhdysosien välissä muutoinkin? Jos joku tutkisi nimenomaan yhdysmerkin käyttöä vanhassa kirjasuomessa, hänen olisi syytä problematisoida tällaiset tekstinkohdat ja tarkistaa kirjoitusasu myös alkutekstistä tai näköispainoksesta. Näin Toropainen onkin toiminut oman tutkimuksensa kannalta kriittisissä kohdissa.

Toropaisen osatutkimusten yhteinen metodinen pohja muodostuu systemaattisesta sanastuksesta ja morfologisesta analyysista, jonka tarkkuus kuitenkin vaihtelee artikkeleittain. Useimmissa osatutkimuksissa hän on myös verrannut havaintojaan Agricolan yhdyssanoista nykyiseen kirjakieleen, joissakin myös suomen murteiden yhdyssanoihin sekä Agricolan jälkeisen vanhan kirjasuomen yhdyssanoihin. Paikoitellen mukana on vertailua Agricolan suomennosten lähdeteksteissä esiintyviin sanarakenteisiin. 


\section{Viisi artikkelia}

Väitöstutkimuksen varhaisimmassa artikkelissa "Vanhan kirjasuomen yhdysverbit" (Sananjalka 2003) Toropainen luo katsauksen koko Ruotsin vallan ajan kirjasuomen yhdysverbien rakenteeseen ja yleisyyteen aineistonaan Turun yliopistossa säilytettävät kopiot Vanhan kirjasuomen sanakirjan (VKS) toimitustyötä varten tehdyistä sanalipuista. Aikarajaus poikkeaa väitöskirjan muista artikkeleista, koska ajatus Agricolan yhdyssanoja koskevasta väitöstutkimuksesta on syntynyt vasta tämän artikkelin julkaisemisen jälkeen. Eri yhdysverbejä on tarkastelussa mukana 1460 . Koko aineiston yhdysverbeistä noin 85 prosentissa on määriteosana tulosijainen adverbi, ja myös kaikki nykykieleen säilyneet vanhat yhdysverbit ovat joko adverbialkuisia tai adverbiin rinnastuvalla nominin taivutusmuodolla alkavia.

Artikkelissa "Mikael Agricolan teosten yhdysadjektiivit" (Virittäjä 2007) Toropainen tarkastelee yhdysadjektiivien morfologista rakennetta pääasiassa edusosan johdostyypin perusteella. Aineisto on kerätty Agricolan teosten morfosyntaktisen tietokannan koodauksista. Mukana ovat myös yhdyspartisiipit, joiden poimintaa on kuitenkin rajoittanut se, että aineiston koodauksessa "on yleensä kiinnitetty huomiota vain yhteen kirjoitettuihin partisiippeihin". Produktiivisia ovat Agricolan aikana olleet -inen- ja -vAinen-loppuiset yhdysadjektiivit sekä yhdyspartisiipit. Artikkeliin sisältyy kiinnostavaa pohdintaa yhdysadjektiivien syntyprosessista, jossa on voinut olla mukana monta vaikuttavaa tekijää: yhtäältä lähtötekstin, toisaalta suomen murteiden tarjoama malli, niin johtaminen kuin yhdistäminenkin. Toropaisen mukaan sellaiset superlatiiviloppuiset yhdysadjektiivit kuin kaikkeinkorkein ovat sittemmin hävinneet kirjoitetusta suomen kielestä - toisin sanoen ne kirjoitetaan nykyään erilleen.

Kolmas artikkeli "Ylen-alkuiset sanat Mikael Agricolan teoksissa" (Sananjalka 2014) on poikkeuksellisesti rajattu yhdyssanan määriteosan mukaan. Agricola on yhdistänyt ylen-sanan paitsi adjektiiveihin ja adverbeihin, myös verbeihin ja substantiiveihin ja tosiaankin 95-prosenttisesti (567:ssä 594 esiintymästä) kirjoittanut sen yhteen seuraavan sanan kanssa. Agricolan teksteissä ylen toimii - ilmeisesti muiden kielten mallin mukaan - sananmuodostusaineksena verbien ja verbeistä johdettujen substantiivien yhteydessä, mutta adjektiiveihin ja adverbeihin liitettynä pikemminkin syntaktisena määritteenä. Sivulla 32 silmään pistää maininta, että artikkelin esimerkeissä nasaaliviivat on korvattu "kursivoidulla nasaalimerkillä"; nasaalimerkin asemesta tässä olisi täsmällisempää puhua nasaalikonsonantista.

Neljäs artikkeli "Adjektiivialkuiset yhdyssubstantiivit Mikael Agricolan teoksissa" (Sananjalka 2015) on osatutkimuksista sivumäärältään laajin. Tarkasteltavana ovat sellaiset adjektiivialkuiset yhdyssubstantiivit (73 lekseemiä), joiden määriteosa voi kongruoida perusosan substantiivin kanssa (esim. makialeipä, uusisyntyminen). Yhdyssanatyyppi on selvästi yleinen ja produktiivinen Agricolan teoksissa, mutta siitä olen kirjoittajan kanssa eri mieltä, että tyyppi olisi myös vakiintunut Agricolan teoksissa. Kun suurin osa esiintymistä on kertaluonteisia, niiden kohdalla olisi ollut hyvä varmistaa, löytyykö Agricolalta vastaavia erilleen kirjoitettuja esiintymiä, liittosanoja. Se, kongruoiko alun adjektiivi edusosan kanssa vai ei, näyttäisi olevan pitkälti adjektiivikohtaista. Kiinnostava kysymys on, osoittaako alkuosan kongruoimattomuus esimerkiksi sanoissa pitkäperjantai ja pyhäpäivä, että yhdyssanan vakiintuminen on jo pitkällä. Vertailussa Agricolan lähdeteksteihin lähes kaikille artikkelin yhdyssubstantiiveista löytyy vastineeksi lekseemi, useimmin sekin yhdyssana.

Viidennessä artikkelissaan ”Typografian vaikutus yhdyssubstantiivien oikeinkirjoitukseen Agricolan teoksissa" (Sananjalka 2016) Toropainen tarkastelee sitä, kuinka tekstin painoasu 
saattaa johtaa luontaisten yhdyssanojen erilleen kirjoittamiseen. Aineistona ovat tällä kertaa Agricolan kootuissa teoksissa esiintyvät yhdyssubstantiivit, joiden määriteosana on substantiivin nominatiivimuoto, yhdysosamuoto tai lekseeminä esiintymätön nominivartalo; tämäntyyppiset yhdyssubstantiivit muodostavat semanttisesti kiinteän kokonaisuuden, ja Agricolan teoksissakin ne on yleensä kirjoitettu yhteen. Noin 5 700:sta luontaisen yhdyssubstantiivin esiintymästä on erikseen kirjoitettuja 415 esiintymää, mutta niistäpä 81 osuu rivinvaihtokohtaan siten, että osien välissä ei ole käytetty yhdysmerkkiä. Agricola-korpuksissa tällaisia tapauksia ei ole erikseen merkitty vaan esiintymät on tulkittu suoraviivaisesti erilleen kirjoitetuiksi. Rivinvaihtokohtiin ei kuitenkaan Agricolan teoksissa eikä muutenkaan 1500-luvulla välttämättä merkitty tavuviivaa, vaan silloinkin saatettiin antaa etusija ladelman tasaisuudelle ja tekstisivun visuaaliselle ilmeelle. Tuskinpa kaikki tällaiset tapaukset ovat ladontavirheitä! Tarkoin harkitulla tutkimusasetelman rajauksella ja Agricolan teosten näköispainosten (MAT) läpi kahlaamisella Toropainen on saanut näkyviin käytänteen, joka olisi muutoin jäänyt piiloon.

\section{Dialogia Vanhan kirjasuomen sanakirjan kanssa}

Tanja Toropainen on käyttänyt tutkimuksessaan alun perin Vanhan kirjasuomen sanakirjaa (VKS) varten koottua aineistoa, sekä sanalippuja että sähköistä Vanhan kirjasuomen korpusta. Tutkija myös kommentoi monessa kohdin sanakirjatyön toimituksellisia ratkaisuja, ennen kaikkea niin sanalippujen kuin valmiiden sana-artikkelienkin hakusanoitusta. Harvoin sanakirjantoimittaja saa käsiinsä tutkimuksen, jossa keskustellaan näin suoraan oman sanakirjan kanssa.

Toropaisen turhauttaviin kokemuksiin epäjohdonmukaisesti hakusanoitettujen ja aakkostettujen sanalippujen ääressä on sanakirjantoimittajan helppo samastua. Ihannemaailmassa sanaliput olisivat valmista tavaraa artikkeliaihioon naputeltaviksi, mutta käytännössä sanalippujen tekemisen ja sana-artikkelin kirjoittamisen välillä voi olla vuosikymmenten viive, eikä yksittäistä teosta sanastettaessa ole vielä pystytty ratkaisemaan esimerkiksi sitä, tulkitaanko jokin verbiesiintymä sanakirjassa yhdysverbiksi vai ei - sen ratkaisun tekee vasta artikkelin kirjoittaja.

Toropainen on aivan oikeassa siinä, että VKS:ssä vanhaa kirjasuomea katsotaan monessa suhteessa ikään kuin nykykielen läpi. Hakusanojen kirjoitusasu on nykykielistetty ja artikkelit on kirjoitettu oletuslukijalle, joka etsii joko tietoa nykykielen sanojen esiintymisestä vanhassa kirjasuomessa tai selitystä vanhassa tekstissä kohtaamalleen oudolle tai vähintäänkin nykykielestä poikkeavalla tavalla käytetylle sanalle. Niinpä hakusanoina saattaa olla sellaisiakin nykyään yhteen kirjoitettavia sanayhtymiä, joita vielä vanhan kirjasuomen kaudella esiintyi vain erilleen kirjoitettuna. Kun sanakirjaa tehtäessä mietitään, tulkitako jokin sanayhtymä yhdyssanaksi vai ei, kieltämättä lisävahvistusta haetaan usein nykykielestä. Uskon kuitenkin, että tällaiset toimitusperiaatteet palvelevat useimpia sanakirjan käyttäjiä paremmin kuin tiukka pitäytyminen vanhan kirjasuomen aikaisessa ortografiassa.

Sanayhtymät, joista on sekä yhteen että erilleen kirjoitettuja esiintymiä, joutuu sanakirjassa esittämään jommankumman kirjoitusasun ehdoilla. Esimerkiksi VKS:n sielunpaimen-artikkeliin on tulossa esimerkkejä Agricolasta alkaen, vaikka yhtymän ensimmäinen yhteen kirjoitettu esiintymä on vasta 1650-luvulta. Ilmaus on kuitenkin ollut jo ennen yhteen kirjoittamista selvästi merkitykseltään eriytynyt, mikä puoltaa sen esittämistä omassa artikkelissaan. Toinen vaihtoehto olisi esittää paimen-artikkelin yhteydessä erilleen kirjoitettu alihakusana sielun 
paimen; alihakusanana esitetään varsinkin sellaisia liittosanoja tai lausekkeita, jotka merkitsevät kokonaisuutena jotakin muuta kuin osien merkityksestä voi suoraan päätellä. Jos yhteen ja erilleen kirjoitettujen esiintymien määrä saisi yksin ratkaista asian, sielun paimen tulisikin sanakirjaan alihakusanana, koska erilleen kirjoitettuja esiintymiä on VKS:n aineistossa moninkertainen määrä verrattuna yhteen kirjoitettuihin.

Adjektiivialkuisia yhdyssubstantiiveja koskevassa artikkelissaan Toropainen vertaa itse keräämäänsä aineistoa VKS:n hakusanoihin ja saa näin esiin sanakirjan "varjoaineistoa", joukon Agricolan käyttämiä adjektiivialkuisia yhdyssubstantiiveja, joita ei kuitenkaan ole esitetty sanakirjassa yhdyssanoina. Esimerkiksi Agricolan Psalttarissa kertaalleen yhteen kirjoitettu kärkäskostaja ei ole saanut omaa artikkeliaan, mutta sanayhtymästä on Agricolalta yhteen kirjoitettu esiintymä kercketkostaiat esimerkkinä kärkäs-artikkelissa ja erilleen kirjoitettu esiintymä kärcken Costaian kostaja-artikkelissa. Sanakirjaa toimitettaessa kärkäs kostaja on siis tulkittu aivan nimellisarvostaan otettavaksi syntagmaattiseksi sanaliitoksi, joka on satunnaisesti kirjoitettu yhteen eikä vaadi edes omaa alihakusanaa.

Tanja Toropaisen laskelmien mukaan Mikael Agricolan teokset sisältävät lähes $2500 \mathrm{yh}$ dyssanalekseemiä ja yli 23700 yhteen kirjoitettua vähintään kahdesta sanasta muodostuvaa esiintymää. Raimo Jussila $(1988,209,213)$ on laskenut Vanhan kirjasuomen sanakirjan ensimmäisen osan ilmestyttyä siitä 346 Agricolan teoksissa esiintyvää yhdyssanalekseemiä, mikä kuudella kerrottuna tuottaisi kokonaismääräksi 2076 yhdyssanalekseemiä (olettaen, että ensimmäinen osa sisältää noin kuudesosan vanhan kirjasuomen sanastosta). Kokonaismäärän eroa selittää paitsi kertaluonteisten yhteen kirjoitettujen sanaesiintymien erilainen käsittely, myös se, että Toropainen on erottanut morfologisin perustein eri lekseemeiksi esimerkiksi nominatiivija genetiivialkuiset yhdyssubstantiivit, jotka taas VKS:ssä on esitetty samassa artikkelissa.

\section{Agricolan yhdyssanat ryhmäkuvassa}

Mikael Agricolan teoksissa on kirjoitettu yhteen sellaisia kokonaisuuksia, joita sitoo toisiinsa ennen kaikkea merkitys, Toropainen kiteyttää. Agricolan teosten yhdyssanat vastaavat sikäli Laura Tyysterin $(2015,26)$ kuvaamaa yhdyssanan prototyyppiä, että ne koostuvat itsenäisistä lekseemeistä ja ovat kiteytyneet yksittäisten käsitteiden nimityksiksi. Monet Agricolan yhdyssanoista ovat morfologisestikin eheitä ja koskemattomia kokonaisuuksia. Toisaalta Agricolan sanayhtymissä on myös höllien yhtymien piirteitä: yhdyssanoissa on suhteellisen tavallista, että määriteosan adjektiivi kongruoi edusosan kanssa ja että omistusliite sijoittuukin sanayhtymän alku- eikä loppuosaan, ja nykykielen yhdyssanaa vastaa usein liittomuotoinen yhtymä tai lauseke (esim. sielun paimen).

Yksi selvitystä kaipaava jatkotutkimusaihe niin Agricolan sanastossa kuin vanhassa kirjasuomessa laajemminkin ovat erilleen kirjoitetut liittosanat ja keskeisenä ryhmänä niiden joukossa genetiivialkuiset substantiiviyhtymät. Liittosanojen tutkimukseen Toropainen peräänkuuluttaa tehokasta semanttista metodia, jonka avulla "lekseemin kaltaiset merkityskokonaisuudet olisi helppo erottaa syntagmaattisista sanaliitoista eikä aineiston keräämisestä tulisi loputon urakka”. Tähän toivomukseen on helppo yhtyä.

Vaikka Agricolan teokset edustavat vain lyhyttä jaksoa kirjasuomen kehityksessä, niissä esiintyvien yhdyssanarakenteiden kuvaus tarjoaa eittämättä hyvän pohjan ja vertauskohdan myöhemmässä kirjallisuudessa esiintyvien yhdyssanojen tutkimukseen. Toropainen on tehnyt vankkaa perustutkimusta myös nuorempien kielimuotojen tutkimuksessa hyödynnettäväksi, ja 
hän on dokumentoinut tutkimusasetelmansa niin tarkkaan, että myöhempien tutkijoiden on mahdollista rakentaa vastaavanlainen asetelma omiin, toisista aineistoista tehtyihin tutkimuksiinsa.

Tanja Toropaisen teksti on kaiken kaikkiaan luontevasti etenevää, helppolukuista ja huoliteltua. Väitöskirjan kaikki osatutkimukset on julkaistu suomeksi; toivottavasti tekijä vielä jossain vaiheessa kirjoittaa aiheesta myös kansainväliselle tiedeyhteisölle.

Sinänsä pieni mutta yhdyssanoja koskevassa tutkimuksessa harmillinen yksityiskohta on suurten lukujen kirjoittaminen yhteen ilman tuhaterotinta (esim. 23700 pro 23 700) - tulkoon se nyt mainituksi, koska numero- ja merkkistandardin sekä kielenhuollon suosituksen vastainen kirjoitusasu toistuu systemaattisesti. Sivulla 50 puhutaan "kaikkein-superlatiivimuodolla alkavista muodosteista", kun tarkoitetaan kaikkein-adverbilla alkavia superlatiivimuodosteita, ja sivulla 70 konjunktio kuin ja siitä yhdistetyt liittokonjunktiot ovat lipsahtaneet adverbien luokkaan. Myös Agricolan syntymäpitäjän nimen taivutus olisi ollut helppo varmistaa: Pernajassa, ei Pernajalla. Relevantti lisä lähteisiin olisi voinut olla Taru Kolehmaisen (2015) tutkimus suomen kielen ohjailun historiasta, jossa myös yhdyssanoja koskevilla ratkaisuilla on tärkeä osansa.

Tanja Toropainen osoittaa, että vaikka vanhan kirjasuomen yhdyssanoja on työlästä tutkia, se on kuitenkin mahdollista. Väitöskirjaan sisältyy monia pienempiä ja suurempia kiinnostavia havaintoja, mutta kokonaisuuden keskeisimpinä anteina pidän yhtäältä yhdyssanan käsitteen arvioimista Agricola-aineiston perusteella, toisaalta eri tavoin koostettujen aineistojen käytön pohdintaa. Toropainen tekee lukijansa tietoiseksi siitä, miten oleellinen osa tutkimusprosessia on tutkimusaineiston kokoaminen ja rajaaminen ja mihin kaikkeen se voi vaikuttaa. Samalla lukija pääsee ravistelemaan yhdyssanoja koskevia ajatusluutumiaan: ehkäpä 1900-luvun kielioppaat ja äidinkielen tunneilla opitut oikeinkirjoituksen nyrkkisäännöt eivät kerrokaan koko totuutta yhdyssanojen olemuksesta.

ELINA HeIKKILÄ elina.heikkila@kotus.fi Kotimaisten kielten keskus Hakaniemenranta 6 o0530 Helsinki

\section{Lähteet}

Inaba, Nobufumi 2007: Mikael Agricolan teokset tietokannan muodossa. KaISA HäKKINEN ja TANJA VaitTinen (toim.): Agricolan aika, 147-161. BTJ Kustannus, Helsinki.

IA = Esko Koivusalo (päätoim.), Irene HellemaA, ANJa LehtimäKi ja RittTa Suhonen (toim.) 1980: Index Agricolaensis I (A-P) - II (Q-Ö, Käänteisluettelo). Kotimaisten kielten tutkimuskeskuksen julkaisuja 11. Kotimaisten kielten tutkimuskeskus, Helsinki.

Jussila, Raimo 1988: Agricolan sanasto ja nykysuomi. Esкo Koivusalo (toim.): Mikael Agricolan kieli, 203-228. Tietolipas 112. Suomalaisen Kirjallisuuden Seura, Helsinki.

Koivisto, Vesa 2013: Suomen sanojen rakenne. Suomi 202. Suomalaisen Kirjallisuuden Seura, Helsinki.

Kolehmainen, TARU 2015: Kielenhuollon juurilla. Suomen kielen ohjailun historiaa. Kotimaisten kielten keskuksen verkkojulkaisuja 41. Saatavilla: http://scripta.kotus.fi/WWW/verkojulkaisut/julk41/ Kielenhuollon_juurilla.pdf $>$. Viittauspäivä: 20.6.2018.

MAT $=$ Mikael Agricolan teokset 1-4. Uudistettu näköispainos. 1987. Werner Söderström Osakeyhtiö, Porvoo-Helsinki-Juva. 
Rapola, MartTi 1933: Suomen kirjakielen historia pääpiirteittäin I. Vanhan kirjasuomen kirjoitus- ja äänneasun kehitys. Suomalaisen Kirjallisuuden Seuran Toimituksia 197. Helsinki.

Ohje Artikkeliväitöskirja humanistisessa tiedekunnassa 2017-2018. Turun yliopisto. Saatavilla: http:// www.utu.fi/fi/yksikot/hum/tutkimus/jatko-opiskelu/jatkotutkinto-opas/Documents/hum-artikkelivaitoskirja-2017-2018.pdf. Viittauspäivä: 20.6.2018.

TyYsteri, LaUra 2015: Aamiaiskahvilasta ötökkätarjontaan. Suomen kirjoitetun yleiskielen morfosyntaktisten yhdyssanarakenteiden produktiivisuus. Annales Universitatis Turkuensis C 408. Turku. Saatavilla: http://urn.fi/URN:ISBN:978-951-29-6184-9. Viittauspäivä: 20.6.2018.

VKS = Vanhan kirjasuomen sanakirja 1-2. Ensimmäinen (A-I) ja toinen (J-K) osa. Kotimaisten kielten tutkimuskeskuksen julkaisuja 33. 1985, 1994. Kotimaisten kielten tutkimuskeskus - Valtion painatuskeskus, Helsinki.

VKS [verkkosanakirja] = Vanhan kirjasuomen sanakirja. Saatavilla: http://kaino.kotus.fi/vks. Jatkuvasti päivitettävä julkaisu, viimeksi päivitetty 17.11.2017 [a-osviitu]. Viittauspäivä: 20.6.2018. 